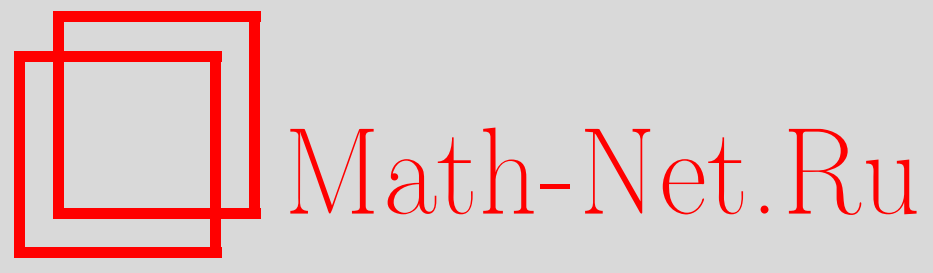

V. P. Kovalev, E. Yu. Prosviryakov, Новый класс невинтовых точных решений уравнений НавьеСтокса, Вестн. Сам. гос. техн. ун-та. Сер. Физ.мат. науки, 2020, номер 4, 762-768

DOI: https://doi.org/10.14498/vsgtu1814

Использование Общероссийского математического портала MathNet.Ru подразумевает, что вы прочитали и согласны с пользовательским соглашением

http://www . mathnet.ru/rus/agreement

Параметры загрузки:

IP : 3.93 .64 .190

26 апреля 2023 г., 04:07:23

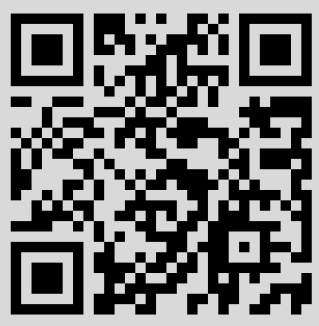


MSC: 76D05, 76D99

\title{
A new class of non-helical exact solutions of the Navier-Stokes equations
}

(C) V.P. Kovalev ${ }^{1}$, E. Yu. Prosviryakov ${ }^{2}$

1 Moscow Institute of Physics and Technology

(National Research University),

9, Institutskiy per., Dolgoprudny, Moscow region, 141701, Russian Federation.

2 Institute of Engineering Science, Urals Branch, Russian Academy of Sciences, 34, Komsomolskaya st., Ekaterinburg, 620049, Russian Federation.

\begin{abstract}
The paper presents a new class of exact solutions for the Navier-Stokes equations. These solutions describe unsteady three-dimensional in velocities and two-dimensional in coordinates for a viscous incompressible fluid flow. The procedure for constructing an exact solution generalizes Trkal's method proposed for studying screw flows. The new class of exact solutions allows to describe non-hecical flows (the velocity vector forms a nonzero angle with the vorticity vector) and fluid flows existing in a finite time.
\end{abstract}

Keywords: Navier-Stokes equation, exact solution, Trkal's method, eigenfunctions of the Laplacian, non-helical flows, blow-up regimes.

Received: $29^{\text {th }}$ July, 2020 / Revised: $18^{\text {th }}$ September, $2020 /$

Accepted: $16^{\text {th }}$ November, $2020 /$ First online: $9^{\text {th }}$ December, 2020

Introduction. The study of the properties of Navier-Stokes equation solutions and continuity equation solutions is known to be based on different approaches, which can be divided into two big groups: analytical research and numerical integration. Analytical research, in turn, is divided into the study of the general properties of flows (one of the latest results were obtained in [1-3]) and the integration of the equations of motion of a viscous incompressible fluid. The mathematical tool for the analytical integration of the equations of motion of a

\section{Short Communication}

() () The content is published under the terms of the Creative Commons Attribution 4.0 International License (http://creativecommons.org/licenses/by/4.0/)

Please cite this paper in press as:

Kovalev V. P., Prosviryakov E. Yu. A new class of non-helical exact solutions of the Navier-Stokes equations, Vestn. Samar. Gos. Tekhn. Univ., Ser. Fiz.-Mat. Nauki [J. Samara State Tech. Univ., Ser. Phys. Math. Sci.], 2020, vol. 24, no. 4, pp. 762-768. https://doi.org/10.14498/vsgtu1814.

\section{Authors' Details:}

Vitalii P. Kovalev (1) https://orcid.org/0000-0001-5116-8135

Cand. Phys. \& Math. Sci; Associate Professor; Dept. of Higher Mathematics;

e-mail: kovalev-falt@yandex.ru

Evgeniy Yu. Prosviryakov (1) https://orcid.org/0000-0002-2349-7801

Dr. Phys. \& Math. Sci.; Head of Sector; Sect. of Nonlinear Vortex Hydrodynamics;

e-mail: evgen_pros@mail.ru 
viscous incompressible fluid for replication of exact solutions is based on group (symmetry) analysis. However, the study of the invariant properties and finding various symmetries of equations gives no way of obtaining all the exact solutions to the Navier-Stokes equations [4]. An important problem of the theory of integration of the equations of fluid motion is constructing classes of exact solutions, which is often heuristic [5-15]. The fact is that classes of exact solutions are known that have yet to be classified in terms of the invariance theory [5-7, 14, 15]. Therefore, it is very important to know how methods for "reproducing" exact solutions can be developed using known flows as examples. This approach was discussed in $[5,9,12,13]$.

It has been shown in recent papers that there are generalizations of the wellknown Trkal method [16] which allow exact solutions to the Navier-Stokes equations to be constructed $[17,18]$. Most of nonstationary three-dimensional exact solutions to the Navier-Stokes equations were obtained by the Trkal method which is an extension of the Taylor-Caldonazzo approach to helical flows [18].

The method is based on the fact that with a constant coefficient $k$ relating velocity vector to vorticity one, velocity vector and vorticity rotor one will also be related by a constant coefficient $k^{2}$. This paper proposes a family of non-helical exact solutions in which the velocity vector and the vorticity one are even noncollinear. However, the velocity and vorticity rotor vectors prove to be related by a constant coefficient, and this eventually enables us to obtain nonstationary exact solutions to the Navier-Stokes equations from stationary exact solutions to the Euler equations. Thus, the here-proposed method can be viewed as an extension of the Trkal method to non-helical flows.

1. Notation and equations of motion. In dimensionless variables, the flow of a viscous incompressible fluid in a potential field of body forces obeys the Navier-Stokes equation system and the continuity equation

$$
\begin{aligned}
\frac{\partial}{\partial t} \mathbf{V}+\boldsymbol{\Omega} \times \mathbf{V}=-\frac{1}{\operatorname{Re}} \boldsymbol{\nabla} \times \boldsymbol{\Omega}-\boldsymbol{\nabla}\left(p+\frac{\mathbf{V}^{2}}{2}+G\right), \\
\operatorname{div} \mathbf{V}=0
\end{aligned}
$$

where $\mathbf{V}$ is velocity, $\boldsymbol{\Omega}=\boldsymbol{\nabla} \times \mathbf{V}$ is vorticity, $p$ is pressure related to density, $\operatorname{Re}$ is the Reynolds number, $\boldsymbol{\nabla}$ is the two-dimensional Hamilton operator, $G$ is the potential of body forces.

2. The family of exact solutions. Consider an arbitrary solution to the equation with respect to the (twice continuously differentiable) function of two variables $\psi=\psi(x, y)$ in a rectangular Cartesian coordinate system Oxyz:

$$
\Delta \psi=\lambda \psi
$$

where $\lambda$ is an arbitrary constant, $\Delta=\frac{\partial^{2}}{\partial x^{2}}+\frac{\partial^{2}}{\partial y^{2}}$ is the two-dimensional Laplace operator. Examples of such solutions (which are the eigenfunctions of the Laplace operator) can be found e.g. in $[4,17,18]$.

For any solution $\psi=\psi(x, y)$ of equation $(3)$, we assume that

$$
\mathrm{V}=\left(V_{x}, V_{y}, V_{z}\right)=\exp \left(\frac{t \lambda}{\operatorname{Re}}\right)\left(\frac{\partial}{\partial y} \psi,-\frac{\partial}{\partial x} \psi, \lambda \psi\right)
$$


It can easily be seen that this representation of velocity provides the inherent (identical) fulfillment of the continuity equation (2). It remains to verify that there exists a pressure field $p>0$ that, together with the velocity represented by equation (4), satisfies equation (1). To do this, we rewrite the Navier-Stokes equation (1) as

$$
\frac{\partial}{\partial t} \mathbf{V}+\frac{1}{\operatorname{Re}} \boldsymbol{\nabla} \times \boldsymbol{\Omega}+\boldsymbol{\Omega} \times \mathbf{V}=-\boldsymbol{\nabla}\left(p+\frac{\mathbf{V}^{2}}{2}+G\right),
$$

and compute the terms in the left-hand side of (5).

The first term in equation (5) is transformed as follows:

$$
\frac{\partial}{\partial t} \mathbf{V}=\frac{\lambda}{\operatorname{Re}} \exp \left(\frac{t \lambda}{\operatorname{Re}}\right)\left(\frac{\partial}{\partial y} \psi,-\frac{\partial}{\partial x} \psi, \quad \lambda \psi\right)=\frac{\lambda}{\operatorname{Re}} \mathbf{V}
$$

Taking into account (3), we obtain the following expressions for the vorticity vector:

$$
\boldsymbol{\Omega}=\lambda \exp \left(\frac{t \lambda}{\operatorname{Re}}\right)\left(\frac{\partial}{\partial y} \psi,-\frac{\partial}{\partial x} \psi,-\psi\right) .
$$

Note that the second term in the left-hand side of (5) coincides up to sign with the first term in equation (6):

$$
\frac{1}{\operatorname{Re}} \nabla \times \boldsymbol{\Omega}=\frac{\lambda}{\operatorname{Re}} \exp \left(\frac{t \lambda}{\operatorname{Re}}\right)\left(-\frac{\partial}{\partial y} \psi, \quad \frac{\partial}{\partial x} \psi,-\lambda \psi\right)=-\frac{\lambda}{\operatorname{Re}} \mathbf{V}
$$

Finally, we compute the third term:

$$
\begin{aligned}
\boldsymbol{\Omega} \times \mathbf{V}=\lambda \exp \left(\frac{2 t \lambda}{\operatorname{Re}}\right)\left(-(\lambda+1) \psi \frac{\partial}{\partial x} \psi, \quad\right. & \left.(\lambda+1) \psi \frac{\partial}{\partial y} \psi, 0\right)= \\
& =-\nabla\left(\frac{\lambda(\lambda+1)}{2} \psi^{2} \exp \left(\frac{2 t \lambda}{\operatorname{Re}}\right)\right) .
\end{aligned}
$$

Substituting expressions (6), (8), and (9) into formula (5), we arrive at the fluid motion equation:

$$
-\nabla\left(\frac{\lambda(\lambda+1)}{2} \psi^{2} \exp \left(\frac{2 t \lambda}{\operatorname{Re}}\right)\right)=-\nabla\left(p+\frac{\mathbf{V}^{2}}{2}+G\right) .
$$

For the velocity field V set by formula (4), the solution of equation (10), and hence equation (1) with respect to the pressure field $p>0$ does exist and it is determined to an arbitrary constant $p_{0}$ ensuring the positivity of the pressure in the region under study as

$$
p=p_{0}-G+\frac{1}{2}\left\{\lambda \psi^{2}-\left(\frac{\partial}{\partial x} \psi\right)^{2}-\left(\frac{\partial}{\partial y} \psi\right)^{2}\right\} \exp \left(\frac{2 t \lambda}{\operatorname{Re}}\right) .
$$

Thus, for any solution $\psi=\psi(x, y)$ of equation (3) and any field of body forces $G$, formulaes (4) and (11) specify the velocity and pressure fields of an exact solution to the Navier-Stokes equations. 
3. The analysis of the obtained solution family. The projection of the velocity (4) onto the plane $O x y$ coincides with the velocities of plane exact solutions obtained in [17]. A comprehensive analysis of these exact solutions was performed in [17]; therefore, in [17], one can become familiar with the projections of the velocities and streamlines of solution (4) for various values of $\lambda$ and for various corresponding functions $\psi$.

It follows from the analysis of the formulaes for the velocity vector (4) and the vorticity vector (7) that they are parallel when $\lambda=-1$. Thus, it is only in the case $\lambda=-1$ that the found exact solution is helical [16-18].

Note that when $\lambda=-1$, one of the solutions to equation (3) is a stream function of the form

$$
\psi=-\cos (x / \sqrt{2}) \cos (y / \sqrt{2}) .
$$

The corresponding velocity field (4) coincides with the known exact Berker solution [19]:

$$
\begin{aligned}
& V_{x}=-\cos (k x / \sqrt{2}) \sin (k y / \sqrt{2}) / \sqrt{2}, \\
& V_{y}=\sin (k x / \sqrt{2}) \cos (k y / \sqrt{2}) / \sqrt{2} \\
& V_{z}=\cos (k x / \sqrt{2}) \cos (k y / \sqrt{2}) .
\end{aligned}
$$

If $k=1$, this exact solution describes the flow of an ideal fluid in an infinite square cross-section pipe $(0 \leqslant x \leqslant \sqrt{2} \pi, 0 \leqslant y \leqslant \sqrt{2} \pi)$.

The construction of the exact solution (4) for the equations of motion of a viscous incompressible fluid (1), (2) is based on finding eigenfunctions of the Laplace equation (3). Recall that this approach was first proposed by Trkal [16]. When the classical Trkal method is applied, the velocity always decreases with time since the exponent is $-t k^{2} / \mathrm{Re}$. In the family of the here-obtained solutions, the velocity can increase with time. This is possible if the function $\psi$ corresponds to the positive value of $\lambda$. Such a stream function can be exemplified the formula

$$
\psi=\exp (2 x) \cos y
$$

The substitution of this function to into formula (11) yields the following pressure distribution in the fluid:

$$
p=p_{0}-G+\frac{\exp (2 x)}{2}\left\{(\lambda-4)(\cos y)^{2}-(\sin y)^{2}\right\} \exp \left(\frac{2 t \lambda}{\operatorname{Re}}\right) .
$$

We assume that $\lambda=3$ in (12), then the expression in the curly brackets proves to be negative $\left((3-4)(\cos y)^{2}-(\sin y)^{2}=-1\right)$. Therefore, the corresponding solution is time-bounded since, with any choice of $p_{0}$, there exists such a point in time that the pressure at some points reaches zero, and there appear caverns (cavities) whose presence prevents from using the Navier-Stokes equations in the entire region under study. The study of such flows is not the subject matter of this paper; yet, the proposed class of exact solutions of the Navier-Stokes equations allows us to describe blow-up flows.

4. Conclusion.The paper has presented a procedure for constructing a new class of exact solutions to the Navier-Stokes equations for a viscous incompressible fluid. The obtaining of the new family of exact solutions is based on the modified Trkal method. The announced solutions of the Navier-Stokes equations have a 
number of interesting properties. We have shown that it is possible to describe not only helical flows, exponentially damped with time, by the Trkal method. We have found examples of non-helical flows of a viscous incompressible fluid existing in finite time. In other words, they simulate fluid motions characterized by blow-up regimes.

Competing interests. We declare that we have no conflicts of interest in the authorship and publication of this article.

Authors' contributions and responsibilities. We are fully responsible for submitting the final manuscript in print. Each of us has approved the final version of manuscript.

Funding. This work was supported by the Russian Science Foundation (project no. 19-19-00571).

\section{References}

1. Sizykh G. B. Helical vortex lines in axisymmetric viscous incompressible fluid flows, Fluid Dyn., 2019, vol. 54, no. 8, pp. 1038-1042. https://doi.org/10.1134/S0015462818060083.

2. Sizykh G. B. Axisymmetric helical flows of viscous fluid, Russ. Math., 2019, vol.63, no. 2, pp. 44-50. https://doi.org/10.3103/S1066369X19020063.

3. Sizykh G. B. Closed vortex lines in fluid and gas, Vestn. Samar. Gos. Tekhn. Univ., Ser. Fiz.-Mat. Nauki [J. Samara State Tech. Univ., Ser. Phys. Math. Sci.], 2019, vol. 23, no. 3, pp. 407-416. https://doi.org/10.14498/vsgtu1723.

4. Pukhnachev V. V. Symmetries in Navier-Stokes equations, Usp. Mekh., 2006, vol.4, no. 1, pp. 6-76 (In Russian).

5. Aristov S. N., Knyazev D. V., Polyanin A. D. Exact solutions of the Navier-Stokes equations with the linear dependence of velocity components on two space variables, Theor. Found. Chem. Eng., 2009, vol.43, no.5, pp. 642-662. https://doi.org/10.1134/ S0040579509050066.

6. Lin C. C. Note on a class of exact solutions in magneto-hydrodynamics, Arch. Rational Mech. Anal., 1957, vol.1, no. 1, pp. 391-395. https://doi.org/10.1007/BF00298016.

7. Sidorov A. F. Two classes of solutions of the fluid and gas mechanics equations and their connection to traveling wave theory, J. Appl. Mech. Tech. Phys., 1989, vol. 30, no. 2, pp. 197203. https://doi.org/10.1007/BF00852164.

8. Meleshko S. V., Pukhnachev V. V. One class of partially invariant solutions of the NavierStokes equations, J. Appl. Mech. Tech. Phys., 1999, vol.40, no.2, pp. 208-216. https:// doi.org/10.1007/BF02468516.

9. Ludlow D. K., Clarkson P. A., Bassom A. P. Similarity reductions and exact solutions for the two-dimensional incompressible Navier-Stokes equations, Stud. Appl. Math., 1999, vol. 103, no. 3, pp. 183-240. https://doi.org/10.1111/1467-9590.00125.

10. Meleshko S. V. A particular class of partially invariant solutions of the Navier-Stokes equations, Nonlinear Dynam., 2004, vol. 36, no. 1, pp. 47-68. https://doi.org/10.1023/B: NODY.0000034646.18621.73.

11. Drazin P. G., Riley N. The Navier-Stokes Equations: A Classification of Flows and Exact Solutions, London Mathematical Society Lecture Note Series, vol. 334. Cambridge, Cambridge Univ., 2006, x+196 pp. https://doi.org/10.1017/cbo9780511526459.

12. Polyanin A. D., Aristov S. N. A new method for constructing exact solutions to three dimensional Navier-Stokes and Euler equations, Theor. Found. Chem. Eng., 2011, vol. 45, no. 6, pp. 885-890. https://doi.org/10.1134/S0040579511060091.

13. Aristov S. N., Polyanin A. D. New classes of exact solutions and some transformations of the Navier-Stokes equations, Russ. J. Math. Phys., 2010, vol. 17, no. 1, pp. 1-18. 15324515. https://doi.org/10.1134/S1061920810010012.

14. Prosviryakov E. Yu. New class of exact solutions of Navier-Stokes equations with exponential dependence of velocity on two spatial coordinates, Theor. Found. Chem. Eng., 2019, vol. 53, no. 1, pp. 107-114. https://doi.org/10.1134/S0040579518060088. 
15. Aristov S. N., Prosviryakov E. Yu. A new class of exact solutions for three-dimensional thermal diffusion equations, Theor. Found. Chem. Eng., 2016, vol.50, no. 3, pp. 286-293. https://doi.org/10.1134/S0040579516030027.

16. Trkal V. Poznámka k hydrodynamice vazkých tekutin, Časopis pro pěstováni mathematiky a fysiky, 1919, vol.48, no.3, pp. 302-311 (In Czech). https://doi.org/10.21136/CPMF. 1919.109099; Trkal V. A note on the hydrodynamics of viscous fluids, Czech. J. Phys., 1994, vol.44, no. 2, pp. 97-106. https://doi.org/10.1007/BF01701186.

17. Prosviryakov E. Yu. Exact solutions to generalized plane Beltrami-Trkal and Ballabh flows, Vestn. Samar. Gos. Tekhn. Univ., Ser. Fiz.-Mat. Nauki [J. Samara State Tech. Univ., Ser. Phys. Math. Sci.], 2020, vol. 24, no. 2, pp. 319-330. https://doi.org/10.14498/vsgtu1766.

18. Kovalev V. P., Prosviryakov E. Yu., Sizykh G. B. Obtaining examples of exact solutions of the Navier-Stokes equations for helical flows by the method of summation of velocities, Proc. of Moscow Institute of Physics and Technology, 2017, vol. 9, no. 1, pp. 71-88 (In Russian).

19. Berker R. Intégration des équations du mouvement d'un fluide visqueux incompressible, Handbuch der Physik, vol. VIII/2. Berlin, Springer, 1963, 384 pp. (In French) 
Вестн. Сам. гос. техн. ун-та. Сер. Физ.-мат. науки. 2020. Т. 24, № 4. С. $762-768$ ISSN: 2310-7081 (online), 1991-8615 (print)

УДК 532.517.2

\section{Новый класс невинтовых точных решений уравнений Навье-Стокса}

(C) В. П. Ковалев ${ }^{1}$, Е. Ю. Просвиряков ${ }^{2}$

1 Московский физико-технический институт (национальный исследовательский университет), Россия, 141701, Московская обл., Долгопрудный, Институтский пер., 9.

2 Институт машиноведения УрО РАН,

Россия, 620049, Екатеринбург, ул. Комсомольская, 34.

\section{Аннотация}

Приведен новый класс точных решений уравнений Навье-Стокса. Эти решения описывают нестационарные трехмерные по скоростям и двумерные по координатам течения вязкой несжимаемой жидкости. Процедура построения точного решения обобщает метод Тркала, предложенный для изучения винтовых течений. Новый класс точных решений позволяет описывать невинтовые течения (вектор скорости образует ненулевой угол с вектором завихренности) и течения жидкости, существующие конечное время.

Ключевые слова: уравнение Навье-Стокса, точное решение, метод Тркала, собственные функции оператора Лапласа, невинтовые течения, режимы с обострением.

Получение: 29 июля 2020 г. / Исправление: 18 сентября 2020 г. Принятие: 16 ноября 2020 г. / Публикация онлайн: 9 декабря 2020 г.

Конкурирующие интересы. Мы заявляем, что у нас нет конфликта интересов в отношении авторства и публикации этой статьи.

Авторская ответственность. Мы несем полную ответственность за предоставление окончательной рукописи в печать. Каждый из нас одобрил окончательную версию рукописи.

Финансирование. Исследование выполнено при финансовой поддержке Российского научного фонда (проект № 19-19-00571).

\section{Краткое сообщение}

○ () Контент публикуется на условиях лицензии Creative Commons Attribution 4.0 International (https://creativecommons.org/licenses/by/4.0/deed.ru)

\section{Образец для цитирования}

Kovalev V. P., Prosviryakov E. Yu. A new class of non-helical exact solutions of the Navier-Stokes equations, Vestn. Samar. Gos. Tekhn. Univ., Ser. Fiz.-Mat. Nauki [J. Samara State Tech. Univ., Ser. Phys. Math. Sci.], 2020, vol. 24, no. 4, pp. 762-768. https://doi.org/10.14498/vsgtu1814.

\section{Сведения об авторах}

Виталий Петрович Ковалев (1D) https://orcid.org/0000-0001-5116-8135

кандидат физико-математических наук, доцент; доцент; каф. высшей математики; e-mail: kovalev-falt@yandex.ru

Евгений Юръевич Просвиряков (1) https://orcid.org/0000-0002-2349-7801 доктор физико-математических наук; заведующий сектором; сектор нелинейной вихревой гидродинамики; e-mail: evgen_pros@mail.ru 